\title{
Model Basis Data dan Implementasinya Dalam Menunjang Pembuatan Data Warehouse Pada Sistem Manajemen Koleksi Museum
}

\author{
Wasino \\ Teknik Informatika, Fakultas Komputer \\ Universitas Tarumanagara \\ Jakarta, Indonesia \\ wasino@untar.ac.id
}

\author{
Bagus Mulyawan \\ Teknik Informatika, Fakultas Komputer \\ Universitas Tarumanagara \\ Jakarta, Indonesia \\ bagus@untar.ac.id
}

\author{
Indrajani \\ Sistem Informasi, Fakultas Komputer \\ Universitas Bina Nusantara \\ Jakarta, Indonesia \\ indrajani@yahoo.com
}

\begin{abstract}
Abstrak
Tujuan penelitian ini adalah untuk menganalisis dan merancang data warehouse pada Sistem Manajemen Koleksi Museum dan membuat laporan yang mendukung penggunaan data warehouse museum di Indonesia. Metodologi penelitian yang digunakan adalah metode literatur, metode pengumpulan data yaitu menggunakan teknik wawancara, metode analisis menggunakan Data Flow Diagram, dan metode desain data warehouse menggunakan metode empat langkah pemodelan dimensi. Hasil penelitian menunjukkan bahwa diperlukan data desain warehouse untuk mendukung museum di Indonesia dalam keputusan di mana data warehouse dapat menyediakan sumber data multidimensi sesuai dengan analisis kebutuhan, mengintegrasikan database antara departemen dalam museum, memiliki struktur granularity tinggi yang mendukung pembuatan laporan menjadi lebih kompak dan memudahkan proses analisis, dan sebagai sumber data dalam penerapan Business Intelligence.
\end{abstract}

\section{Kata Kunci: Data Warehouse; Museum Indonesia; Integrasi; Four Step Dimensional}

\section{Pendahuluan}

Indonesia memiliki sejarah dan budaya yang beraneka ragam, yang berkembang dari jaman dahulu kala hingga saat ini. Kekayaan sejarah dan budaya ini harus tetap terpelihara sebagai kekayaan budaya nasional Indonesia. Salah satu media untuk memelihara sejarah dan budaya tersebut adalah museum. Museum sangat berperan dalam pemeliharaan kebudayaan nasional, karena museum dapat menyediakan informasi tentang sejarah dan kejadian yang terjadi, khususnya di masa lampau bagi generasi saat ini. Museum didirikan dengan tujuan untuk menciptakan lembaga yang melestarikan warisan budaya yang dimiliki Indonesia, bukan hanya melestarikan warisan budaya secara fisik tetapi juga tetapi juga makna dan sejarah yang terkandung dibalik benda-benda tersebut.

Museum memiliki banyak arti, salah satunya, berdasarkan definisi yang diberikan International Council of
Museums disingkat ICOM, adalah institusi permanen, nirlaba, melayani kebutuhan publik, dengan sifat terbuka, dengan cara melakukan usaha pengoleksian, mengkonservasi, meriset, mengomunikasikan, dan memamerkan benda nyata kepada masyarakat untuk kebutuhan studi, pendidikan, dan kesenangan. Museum menjadi sebuah tempat untuk penyimpanan, perawatan, pengamanan, dan pemanfaatan benda-benda bukti materiil hasil budaya manusia. Dari pengertian tersebut dapat disimpulkan bahwa museum memiliki arti yang penting dalam bagi kehidupan manusia.

Dengan koleksi yang dimilikinya, museum-museum ini memiliki potensi untuk menjadi pusat wisata di Jakarta, akan tetapi sayangnya apresiasi masyarakat Indonesia terhadap museum masih sangatlah minim. Dari data yang dimiliki Badan Perencanaan Pembangunan Nasional (BAPPENAS), jumlah pengunjung museum dari tahun ke tahun terus mengalami penurunan. Data pengunjung 


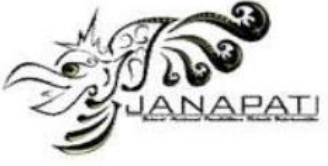

museum secara keseluruhan di Indonesia pada tahun 2006 terdapat 4,56 juta pengunjung, turun menjadi 4,20 juta pengunjung pada tahun 2007, dan turun lagi pada tahun 2008 menjadi 4,17 juta pengunjung [1]. Hal ini sangat disayangkan karena di museum tersimpan berbagai macam pengetahuan dan dapat menjadi sarana pendidikan bagi masyarakat, tetapi mengapa selama ini masyarakat masih menganggap museum hanyalah sebagai tempat menyimpan barang - barang antik yang membosankan? Terdapat dua aspek penting yang perlu diperhatikan dalam pengembangan museum, aspek pertama adalah ketersediaan media informasi untuk mengenalkan museum, aspek kedua adalah ketersediaan sistem pengelolaan data benda koleksi museum.

Kurangnya minat pengunjung menjadi juga menjadi salah satu masalah utama yang dihadapi museum yang ada di Indonesia. Penyebab utamanya mungkin adalah kurangnya informasi kepada masyarakat tentang keberadaan Museum Bahari sendiri. Hanya sedikit orang yang mengetahui tentang keberadaan dan koleksi yang dimilikinya. Dibutuhkan sebuah media informasi yang tepat dan dapat menyebarkan informasi yang lengkap, cepat dan tepat untuk lebih mengenalkan museum kepada calon pengunjung baik yang berasal dari dalam negeri dan luar negeri. Walaupun terdapat beberapa media yang telah memiliki website sebagai media informasi, tetapi informasi yang disajikan kurang lengkap. Misalnya untuk informasi koleksi, hanya sebagian kecil saja koleksi yang ditampilkan dan hanya informasi secara umum saja.

Masalah lain yang dihadapi museum adalah pengelolaan data koleksi. Museum tidak dapat dipisahkan dari koleksinya. Koleksi merupakan hal utama dari sebuah museum yang harus disajikan dalam bentuk komunikasi yang penting dalam menarik minat pengunjung. Informasi yang disampaikan harus bersifat komunikatif dan informatif dengan memberikan informasi yang selengkap mungkin tentang sebuah benda koleksi. Informasi yang lengkap tentang keberadaan sebuah koleksi juga merupakan bentuk proteksi terhadap koleksi museum, untuk menghidari terjadinya kehilangan benda koleksi. Saat ini pengelolaan data koleksi museum masih dilakukan secara manual, disimpan dalam bentuk arsip. Belum ada penyimpanan data dalam bentuk system penyimpanan secara elektronik. Penyimpanan data dalam bentuk arsip kertas memiliki beberapa resiko yang perlu diperhatikan. Resiko yang pertama adalah hilangnya arsip yang berarti hilangnya data benda koleksi, resiko yang lain adalah sulitnya melakukan pencarian data saat diperlukan. Oleh karena itu, sudah saatnya museum memiliki sebuah sistem manajemen koleksi yang berbasis teknologi informasi untuk menyimpan data benda koleksi ke dalam sebuah basis data yang dapat menyimpan data secara terintegrasi dan dapat menyanjikan informasi dengan cepat
ISSN 2087-2658

Jurnal Nasional Pendidikan Teknik Informatika (JANAPATI)

Volume 5, Nomor 2, Juli 2016

\section{MODEL BASIS DATA dan IMPLEMENTASINYA}

\section{A. Sistem Yang Sedang Berjalan}

Hasil analisis terhadap sistem berjalan secara umum digambarkan dalam diagram konteks yang terdiri dari input ataupun output yang berhubungan dengan entitas ekternal. Terdapat 5 (lima) entitas yaitu kepala koleksi dan perawatan, kepala pameran dan edukasi, kepala tata usaha, pengunjung website, dan kepala museum [6]. Gambar diagram konteks dapat dilihat pada gambar berikut ini :

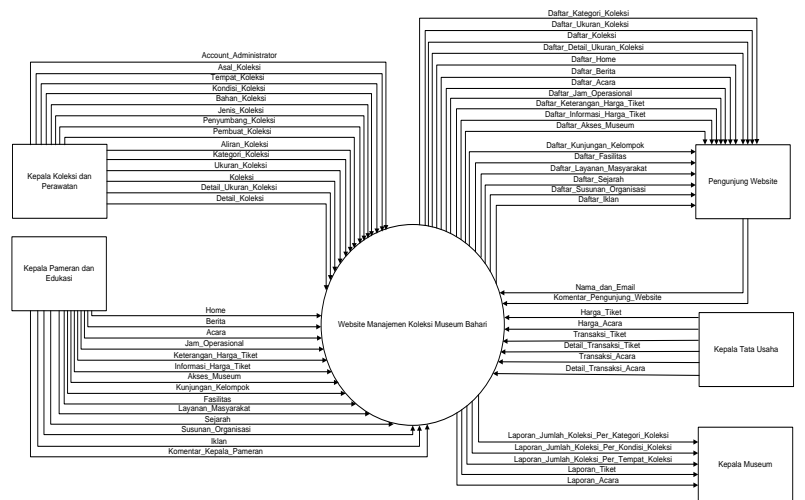

Gambar 1. Diagram Konteks.

Diagram Konteks merupakan diagram yang bersifat gambaran menyeluruh dan akan diperinci ke dalam diagram-diagram yang paling sederhana (primitif), ke dalam bentuk DFD (Data Flow Diagram) level 0 sampai dengan level-n (primitif).

Diagram berikut adalah dekomposisi dari Diagram Konteks, yang didekomposisi menjadi 5 (lima) proses sebagai berikut :

\section{a. Proses 1.0 - Data Master}

Proses yang akan digunakan untuk mengelola perekaman data subyek dari museum. Data yang disimpan adalah data administrator, data asal koleksi, data tempat koleksi, data kondisi koleksi, data bahan koleksi, data jenis koleksi, data penyumbang koleksi, data pembuat koleksi, data kategori koleksi, data ukuran koleksi, data detil ukuran koleksi, detail koleksi, data aliran koleksi, dan data koleksi. Proses ini menghasilkan 14 data store atau tabel untuk menyimpan data subyek. Dari proses ini dihasilkam 4 keluaran atau daftar yaitu daftar kategori koleksi, daftar ukuran koleksi, daftar koleksi, dan daftar ukuran koleksi secara detil yang dapat diakases oleh pengunjung museum.

\section{b. Proses 2.0 - Informasi}

Proses yang akan digunakan untuk pengelolaan pengunjung museum, proses ini terdiri dari data masukan yang berasal dari Kepala Pameran dan Edukasi yang terdiri dari data home (catatan tanggal administrator terdaftar), data 


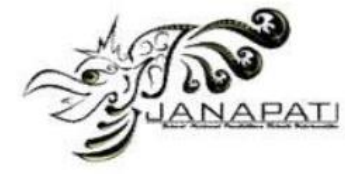

berita, data acara, data jam operasional, data keterangan harga tiket, informasi harga tiket, data akses museum, data kunjungan kelompok, data fasilitas museum, data layanan masyarakat, data sejarah, data susunan organisasi, dan data iklan. Pada proses ini ada 13 masukan yang disimpan ke dalam 13 data store atau tabel. Laporan atau informasi yang dihasilkan pada proses ini terdiri dari 13 keluaran atau informasi.

\section{c. Proses 3.0 - Memberi Komentar}

Proses yang digunakan untuk mengelola data pengunjung museum secara online, data komentar pengunjung, dan data komentar kepala pameran yang dapat dibaca oleh pengunjung. Pada proses ini ada 3 masukan yang disimpan ke dalam 2 data store atau tabel sebagai hasil proses.

\section{d. Proses 4.0 - Administrasi Pengunjung}

Proses yang digunakan untuk mengelola data harga tiket, data harga acara, data transaksi tiket, data detail transaksi tiket, data transaksi acara, dan data detail transaksi acara. Pada proses ini ada 6 data masukan yang disimpan ke dalam 6 data store atau tabel sebagai data hasil proses.

\section{e. Proses 5.0 - Membuat Laporan}

Proses yang digunakan untuk pengelolaan laporan kepada Kepala Museum. Pada proses ini, menghasilkan laporan yang terdiri dari laporan jumlah koleksi per kategori koleksi, laporan jumlah koleksi per kondisi koleksi, laporan jumlah koleksi per tempat koleksi, laporan tiket, laporan acara. Pada proses ini ada 5 laporan yang diberikan kepada Kepala Museum.

Analis harus memeriksa sebuah model data konseptual dan menentukan apakah ada satu kesalahan atau lebih yang terjadi [4].

\section{B. Model Basis Data}

Basis data merupakan model yang menggambarkan hubungan antar entitas [2]. Model ini dapat diterjemahkan kedalam model relasional, dan dapat diuraikan seperti ERD berikut ini:
ISSN 2087-2658

Jurnal Nasional Pendidikan Teknik Informatika (JANAPATI)

Volume 5, Nomor 2, Juli 2016

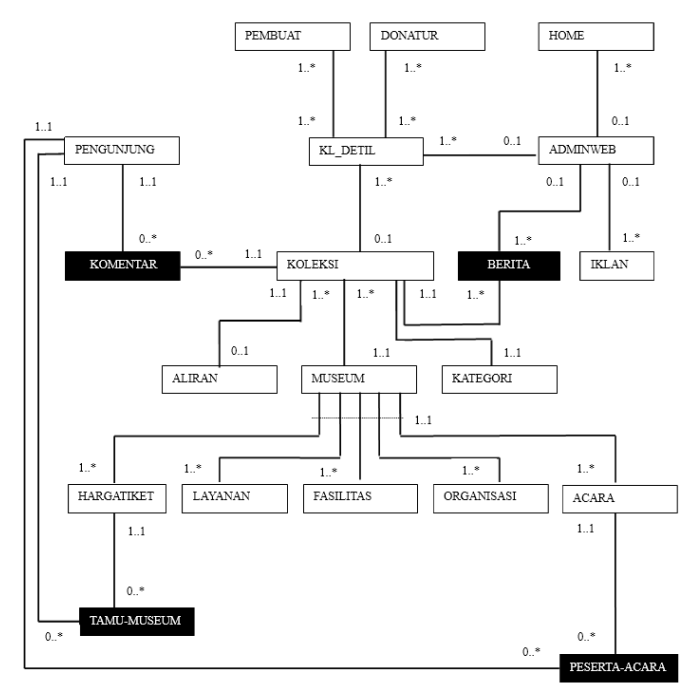

Gambar 2. ERD sistem manajemen koleksi museum

Dalam gambar ini, Model DB Logika (A) dan Model DB Logika (B) adalah sistem basis data yang berbeda. Itu berarti bahwa mereka mungkin memiliki model basis data logika yang berbeda, misalnya basis data relasional dan basis data orientasi-objek, atau mereka mungkin produk basis data yang berbeda, misalnya Oracle dan DB2, meskipun mereka memiliki model basis data logika yang sama. Hal ini dapat dilihat dari gambar bahwa sebuah model data konseptual yang dikembangkan dapat dipetakan ke dalam model basis data logika yang berbeda. Selain itu, juga dapat terlihat bahwa sebuah model basis data logika dapat dipetakan ke dalam sebuah model data konseptual. Konversi ini disebut basis data rekayasa yang terbalik. Jelas bahwa itu memungkinkan model basis data logika yang berbeda dapat dikonversikan satu sama lain melalui rekayasa basis data yang terbalik [7].

\section{Desain Data Warehouse}

\section{A. Menetapkan Proses, Grain, Tabel Dimensi, dan Tabel Fakta}

Pemilihan proses mengacu pada subyek data mart tertentu, yang harus diperhatikan adalah yang paling mungkin untuk mejawab pertanyaan dalam mendukung pengambilan keputusan, sesuai dengan waktu yang dianggap sah atau benar pada saat dianalisis. Kebutuhan data yang terkait dengan proses ditunjukkan pada Hubungan Antar Entitas (ER Model) seperti gambar 2 yang telah disederhanakan dengan hanya memberi label pada entitas dan hubungannya. Proses yang teridentifikasi pada Sistem Manajemen Koleksi Museum ditandai dengan warna hitam tebal pada setiap tabel pada gambar 2, yang terdiri dari: (1) komentar, (2) berita, (3) tamu-museum, (4) peseta-acara. Proses yang dipilih untuk menjadi data mart dalam desain datawarehouse adalah tamu-museum, dan peserta-acara. 


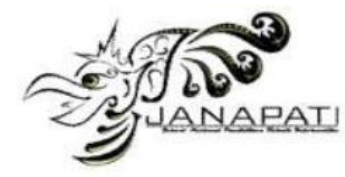

Bagian dari ER model asli yang merupakan kebutuhan data proses tamu-museum, komentar, dan peserta-acara ditunjukkan pada gambar 3. Rancangan secara logika dibuat berdasarkan entitas tamu-museum secara detil terdiri dari transaksi_tiket dan detail_transaksi_tiket. Hasil evaluasi impelementasi sistem menghasilkan kebutuhan baru bahwa pengunjung harus dicatat dalam transaksi kunjungaan, sehingga dihasilkan entitas tamu-museum.

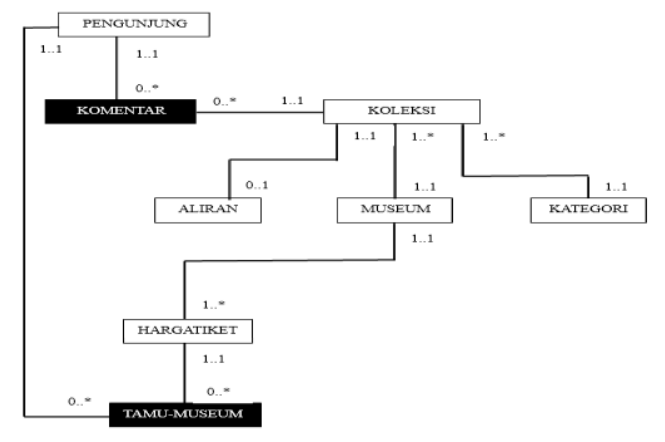

Gambar 3. Bagian ER Model yang Mewakili Kebutuhan Data Proses Tamu-Museum dan Komentar

Rancangan secara logika yang ditunjukkan pada gambar 2, bahwa entitas peserta-acara secara detil terdiri dari harga_acara, transaksi_acara dan detail_transaksi_acara. Hasil evaluasi impelementasi sistem menghasilkan kebutuhan baru bahwa pengunjung harus dicatat dalam transaksi acara, sehingga dihasilkan entitas peserta-acara.

Memilih grain berarti memutuskan data apa yang menjadi simpanan pada tabel fakta. Misalnya, entitas komentar, dan tamu-museum yang ditunjukkan pada gambar 2 merupakan fakta tentang setiap tamu pada museum dan pengunjung yang memberikan komentar terhadap koleksi museum, peserta-acara merupakan fakta tentang seiap peserta yang mengikuti acara. Ketika grain kita pilih, kita dapat mengidentifikasi dimensi untuk tabel fakta. Gambar 3 digunakan untuk referensi data tentang tamu-museum, dan komentar yang akan menjadi tabel dimensi dari skema konstelasi fakta (fact constalation), dan termasuk dimensi waktu yang harus selalu ada dalam desain data warehouse. Model dimensi yang berisi lebih dari satu fakta dan satu tabel atau lebih dari satu tabel yang serupa, disebut sebagai konstelasi fakta [3]. Sebaliknya desain data warehouse yang memiliki satu tabel fakta dan memiliki satu atau lebih tabel dimensi yang mengitarinya, disebut sebagai skema bintang.

\section{B. Merancang Data Warehouse dengan Model Star Schema dan Fact Constalation}

Model dimensional adalah suatu teknik desain secara logika yang menjadikan data cepat untuk diakses. Model dimensional terdiri dari satu atau lebih tabel fakta dan banyak tabel dimensi. Ada tiga macam skema dalam model dimensional yaitu [5] :
- Skema Bintang (Star Schema), suatu struktur logika yang memiliki tabel fakta berisi data faktual dan di kelilingi tabel dimensi yang isinya data pendukung.

- Skema Snowflake (Snowflake Schema), varian lain dari skema bintang. Tabel dimensi tidak mengandung data yang denormalisasi.

- Skema Starflake (Starflake Schema), merupakan gabungan antara skema bintang dan snowflake. Dimensinya terdiri dari data denormalisasi dan data normalisasi, disebut sebagai fakta konstelasi [3].

Model DM (dimension modeling) berbeda dengan model ER (entity relationship), model DM digunakan dalam rancangan data warehouse, sedangkan model ER digunakan dalam melakukan rancangan basis data. Model DM terdiri dari beberapa tabel fakta dan tabel dimensi. Komponen desain data ware house untuk skema konstelasi fakta dan skema bintang ada dua yaitu:

- Tabel Fakta, disebut juga tabel mayor yang berisi primary key bersifat composite yang berasal dari setiap primary key dari tabel dimensi, dan setiap atribut harus bersifat numerik dan akses pengelolaan selalu melalui tabel fakta.

- Tabel Dimensi, disebut juga tabel minor yang berisi gambaran data yang ada pada tabel fakta, berisi informasi tambahan yang diperlukan tabel fakta, setiap atribut kunci sama persis dengan salah satu komponen kunci komposit dalam tabel fakta dengan melakukan penggantian kunci karena harus bersifat numerik.

Grain pada tabel fakta menentukan fakta yang dapat digunakan dalam data mart. Atribut fakta harus bersifat numerik dan aditif. Fakta tidak tidak boleh menggunakan: fakta non-numerik, fakta non-aditif, fakta pada tingkat kedetilan data yang berbeda dari fakta yang ada pada tabel lain. Desain data warehouse dengan skema konstelasi fakta yang didesain berdasarkan ER Model gambar 3 ditunjukkan pada gambar 4, sedangkan desain data warehouse dengan skema bintang yang didesain ditunjukkan pada gambar 5 .

Terdapat dimensi yang teradi pada dua data mart, dimensi itu haruslah persis sama, atau merupakan bagian secara matematis, maka dua data mart berbagi bersama dalam penggunakan data dala aplikasi sama maupun berbeda. Ketika dimensi digunakan oleh lebih dari satu data mart, diemensi ini disebut sebagai dimensi yang sesuai (conformed). 

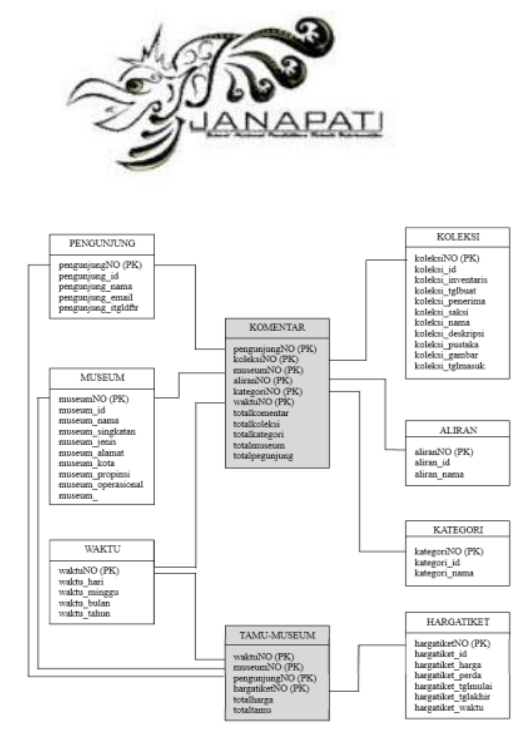

Gambar 4. Desain Data Warehouse skema Konstelasi Fakta - Skema Bintang untuk Komentar dan Tamu-Museum dengan Pengunaan Tabel Dimensi Bersama (pengunjung, museum, dan waktu)

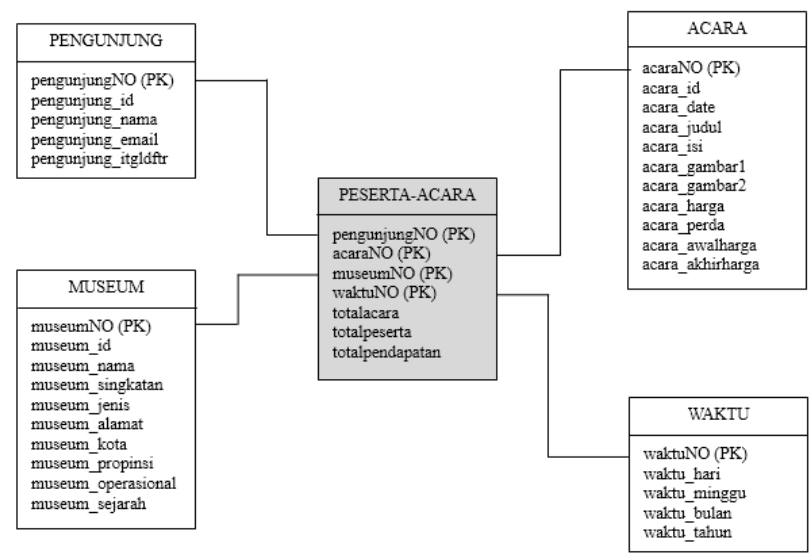

Gambar 5. Desain Data Warehouse dengan Skema Bintang untuk Komenter

\section{EVALUASI}

Dari hasil evaluasi yang dilakukan setelah penerapan data warehouse museum ini, diketahui bahwa penggunaan aplikasi tersebut memberikan beberapa manfaat bagi pihak museum, yakni:

- Data warehouse yang telah dikembangkan tersebut dapat membantu pihak manajemen atas dalam melakukan analisis dan menentukan kebijakan museum yang harus diambil.

- Aplikasi data warehouse tersebut dapat menyajikan berbagai jenis laporan museum, baik dalam bentuk tabel maupun grafik, sesuai dengan keinginan dan kebutuhan pemakainya.
ISSN 2087-2658

Jurnal Nasional Pendidikan Teknik Informatika (JANAPATI)

Volume 5, Nomor 2, Juli 2016

- Penyajian laporan dapat dilakukan dalam waktu yang relatif lebih cepat karena data untuk pembuatan laporan telah diintegrasikan secara menyeluruh ke dalam suatu tempat penyimpanan khusus

\section{PENUTUP}

Setelah menganalisis dan merancang data warehouse pada museum, maka dapat disimpulkan sebagai berikut:

- Data warehouse yang dirancang menghasilkan empat belas dimensi dan empat fakta, yaitu Dimensi Karyawan,Dimensi Pengunjung,Dimensi Museum,Dimensi Fasilitas,Dimensi Layanan,Dimensi Layanan,Dimensi Museum,Dimensi Aliran Koleksi,Dimensi Kategori,Dimensi Koleksi,Dimensi Donatur,Dimensi Pembuat, Dimensi Waktu, Dimensi Wilayah, Fakta komentar,Fakta Berita,Fakta Acara,dan Fakta Iklan.

- Data warehouse menghasilkan laporan yang dapat digunakan untuk analisa mendalam oleh tim eksekutif karena data warehouse dapat menampilkan informasi dari beberapa sudut pandang.

- Data warehouse mendukung pembuatan laporan yang bersifat khusus dan mendadak (ad-hoc reporting).

- Data warehouse yang dihasilkan mampu menjadi sumber data bagi penerapan BI di masa mendatang

\section{DAFTAR PUSTAKA}

[1] BPS, Sensus Penduduk, 2010, diunduh dari http://sp2010.bps.go.id/index.php.

[2] Indrajani,. Perancangan Basis Data Dalam All In 1, ISBN 978-97927-9980-4, Jakarta: Elex Media Computindo, 2011.

[3] Inmon, William H, , Building the Data Warehouse, Fourth Edition, Wiley Publishing, Inc, 2005.

[4] Klein, Barbara, Summer, A Theoretical Framework and Research Agenda for Understanding the Detection of Errors in Conceptual Data Models, Journal of Global Business Issues 2, 2008, pp.183$189 . \quad$ Diunduh dari http://search.proquest.com/docview/223741451 ?accountid=31532

[5] Thomas Connolly and Carolyn Begg, "Database Systems: A Practical Approach to Design, Implementation, and Management", 6rd Edition, Addison Wesley, 2015.

[6] Wasino, Tonny, Bagus, Indrajani, "Perancangan Proses dan Bisnis Data Pengelolaan Koleksi Museum”, DISC 2014, Bandung, 2014.

[7] Z.M.Ma , Engineering information modeling in databases: needs and constructions, Industrial Management + Data Systems volume 105 issue 7, 2005, pp. 900-918, diunduh dari

http://search.proquest.com/docview/234907416?accountid=31532. 